\title{
Correction to: Cardiac magnetic resonance-guided limited ablation of incessant ventricular tachycardia in thrombosed left ventricle
}

\author{
Markus Linhart $^{1} \cdot$ Francisco Alarcón ${ }^{1} \cdot$ Susana Prat-Gonzalez ${ }^{1} \cdot$ José Tomás Ortiz $^{1} \cdot$ Lluís Mont $^{1} \cdot$ Ivo Roca-Luque $^{1}$
}

Published online: 22 May 2020

(C) Springer Science+Business Media, LLC, part of Springer Nature 2020

Correction to: Journal of Interventional Cardiac Electrophysiology https://doi.org/10.1007/s10840-020-00723-z

The original version of this article unfortunately contained a mistake. Francisco Alarcón, Susana Prat-Gonzalez, José Tomás Ortiz, Lluís Mont and Ivo Roca-Luque were not listed among the authors.

Publisher's note Springer Nature remains neutral with regard to jurisdictional claims in published maps and institutional affiliations.

The online version of the original article can be found at https://oi.org/ 10.1007/s10840-020-00723-Z

Markus Linhart

linhart@uni-bonn.de

1 Arrhythmia section, Cardiology Department, Cardiovascular Institute, Hospital Clínic de Barcelona, Barcelona, Spain 